\title{
CIZ1 Gene
}

National Cancer Institute

\section{Source}

National Cancer Institute. CIZ1 Gene. NCI Thesaurus. Code C106349.

This gene plays a role in the regulation of DNA replication. 